\title{
HYDROLOGICAL ASSESSMENTS OF SOME RIVERS IN EDO STATE, NIGERIA FOR SMALL-SCALE HYDROPOWER DEVELOPMENT
}

\author{
C. N. Emeribe ${ }^{1,}{ }^{*}$, E. T. Ogbomida ${ }^{2}$, O.A Fasipe ${ }^{3}$, O. Biose ${ }^{4}$, I. Aganmwonyi ${ }^{5}$, M. Isiekwe ${ }^{6}$ and I. P. Fasipe ${ }^{7}$

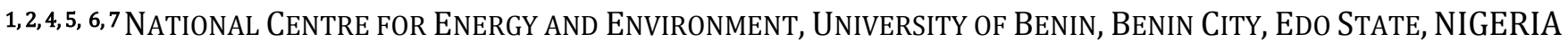 \\ 3, ENERgy CoMmission of NIGERIA, CENTRAL Business District, P.M.B 358, GARKI, ABUjA. NIGERIA \\ E-mail addresses:1 emeribe.c@ncee.org.ng, 2 ogbomida.e@ncee.org.ng,3 fasipeo@gmail.com, \\ 4 bosadebe@yahoo.com,5reemzy2001@yahoo.co.uk,6gbenede77@gmail.com, \\ 7 iriagbonse.fasipe@uniben.edu
}

\begin{abstract}
The aim of this study is to determine the hydro-power potentials of selected rivers in Edo State using hydrological indices. Four Rivers were investigated namely Ovia, Ikpoba Edion, Orlie Rivers. Discharge measurement was carried out for 12 calendar months, from January 2013 to December 2013 using the grid point technique, commonly known as velocity-area method while Gross Hydropower Potential GHP was determined using model developed by UNIDO. Highest monthly hydropower yields were recorded in September for Ovia, Ikpoba and Edion Rivers and in August for Orlie River. On annual basis, Ovia River, recorded the highest power yield of 61.619MW (suggesting that Ovia river may be suitable for a Medium hydropower scheme, 10MW-100MW) with the highest monthly power yield of 42.381MW recorded in September, followed by August (7.047MW). Lowest power yield of $0.019 M W$ was recorded in February.In Ikpoba River, annual hydropower yield was recorded as 14.78MW, while the lowest power yield of 0.02MW was recorded in April. Highest yield of 5.76MW was recorded in september.River Orlie recorded an annual hydropower yield of 9.819 MW, with August having the highest power yield of 3.296MW. Other significant hydropower yield values were recorded in September and July.Edion River has an annual power yield of 5.49MW. Lowest yield in this river was recorded in April..The dependability of flow for hydropower operations were evaluated using the Flow Duration Curve (FDC). The results showed that extreme high monthly discharge volumes of $544.8 \mathrm{~m}^{3}$ in Ovia river, $172 \mathrm{~m}^{3}$ in Ikpoba river, $102.1 \mathrm{~m}^{3}$ in Orlie and $57.1 \mathrm{~m}^{3}$ in Edion have dependability percentages of less than 10\%. Notwithstanding the hydrological conditions of these rivers can be categorized as adequate (15\%-40\%) to average moisture conditions (40\%-60\%).
\end{abstract}

Keywords: Stream discharge, hydropower potential, discharge volume, Flow Duration Curves

\section{INTRODUCTION}

In Nigeria with a population of over 160 million people, it has been shown that more than 15.3 million households in the country lack access to grid electricity; and for those connected to the national grid, supply is unstable. Per capita electricity consumption has been less than 150KWh per annum [1]. The rural areas suffer the most electricity deprivation, as more than $60 \%$ of those living in the rural communities lack access to electricity.

The energy associated with this flowing water is known as kinetic energy that is released through the friction of flowing water with the rocks and the sediment in the river beds. Harnessing the kinetic energy from the flowing water for driving turbine generates hydropower [2]. Hydropower projects are having an overall installed capacity of $990 \mathrm{GW}$ worldwide as of 2012 ( $<10 \mathrm{MW})$. Out of this stated capacity, small hydro ( $<10 \mathrm{MW})$ currently contributes over 40GW of world capacity [3].

The capacity for most stand-alone small hydro systems not interlinked to the grid and suitable for "run-of-the-river" installation can reach up to $500 \mathrm{~kW}$ to $30 \mathrm{MW}$, and the potential depend on the availability of a suitable water flow $[4,5]$. The global small hydro potential is believed to be in excess of $100 \mathrm{GW}$. China is world leader in term of both large and small hydropower capacity and has developed more than 15 
GW of small hydropower and plans to develop a further $10 \mathrm{GW}$ in the current decade [6]. Many researchers across the globe had undertaken studies on small hydropower development in their respective regions [7 - 11]. It is estimated that $12 \%$ of the world's hydro potential is found in Africa - and due to geographical conditions most of it is located in the Sub-Saharan part [12]. Where the resource exists a stand-alone small hydropower system can provide cheap, clean and reliable electricity. Studies have shown that a well-designed small-scale hydropower system can blend with its surroundings and have minimal negative environmental impacts compared to large hydropower projects [13, 14]. Notwithstanding, this favourable condition, the gap between actual hydropower generation and the technologically exploitable potential in Africa has been reported to be very wide, where only $5 \%$ of the potential is currently tapped [12]. Meanwhile, for any meaningful small hydropower project, data on hydrological processes are fundament and required at both the design and operational stages. Such data are necessary for understanding the river behaviour as well as for building predictive models. Previous studies have reported that the amount of achievable hydropower at any given site is a function of turbine head and the corresponding flow rate $[2,15]$. Unfortunately, studies have shown that gathering reliable, long-term and consistent information on river discharges for most basins in developing countries is either lacking or grossly inadequate where they are available $[16,17]$. This may be attributed to the general absence of functional gauging stations along most stream channels in the country $[18,19]$. Others have also linked the problem to cost and time involved in discharge data generation [15]. Several consequences of such disjointed and inaccurate information for water development including hydropower development have been reported to include poor motivation for hydropower development, sluggish growth of hydropower particularly in developing countries [2] and eventual failure of water resources projects [20]. In Edo State which well-endowed with abundance of surface water resources that can be harnessed for rural hydropower project, the situation is not different and as result the hydrological characteristics of most of these rivers in terms of their potentials for small hydropower projects are yet to be fully understood.. The present study was therefore carried out to evaluate the hydropower potentials of
Rivers Edion, Orlie, Ovia and Ikpoba using the AreaVelocity discharge generation method.

\section{MATERIALS AND METHODS}

\subsection{Study Area}

The study area is Edo state. Four Rivers were randomly selected across the State for this survey (Figure 1). These are Rivers Edion, Orlie, Ovia and Ikpoba, which are spatially distributed between Edo north and south. River selection for these rivers was largely guided by the seasonal nature of rivers and the fact that the selected rivers are part of Thematic Group Research Projects of the National Centre for energy and Environment, University of Benin where the authors work.Edo north experiences the humid tropical climate according to the Köppen climatic classification scheme. Rainfall in the area depends on the interaction of the tropical maritime $(\mathrm{mT})$ and tropical continental (cT) air masses which meet along the Inter-Tropical Divergence (ITD). The annual rainfall in the north occasionally exceeds $2000 \mathrm{~mm}$, with a bimodal distribution. The first peak occurs in July with monthly precipitation of $344.7 \mathrm{~mm}$ and the second in September with $457.2 \mathrm{~mm}$ [21]. Most of the storms are convective outbursts and they have shortterm intensities. The high intensities of rains in this region produce high volumes of overland flow with high erosive energy. The highest mean monthly temperature of $29.1^{\circ} \mathrm{C}$ is recorded in March and the lowest of $24.4^{\circ} \mathrm{C}$ in June [22] . In the southern part of the state, rainy season begins in March/April and ends in October/November. Rainfalls are usually of high intensity with double maxima and a dry little spell in August usually referred to as 'August Break' [23]. Annual rainfall amount in the southern part of Edo State ranges from 1800 to $2780 \mathrm{~mm}$. In this study small-scale hydropower is referred to as schemes of $10 \mathrm{MW}$ or less in accordance with classification criteria proposed by [4] (Table.1).

\subsection{Conceptual Framework}

Stream discharge from a river refers to the quantity of water that is available from the basin at any given point and over a specified duration of time. Basin discharge has also been used interchangeably with stream discharge, stream flow, basin runoff, basin yield, catchment's yield [24]. 


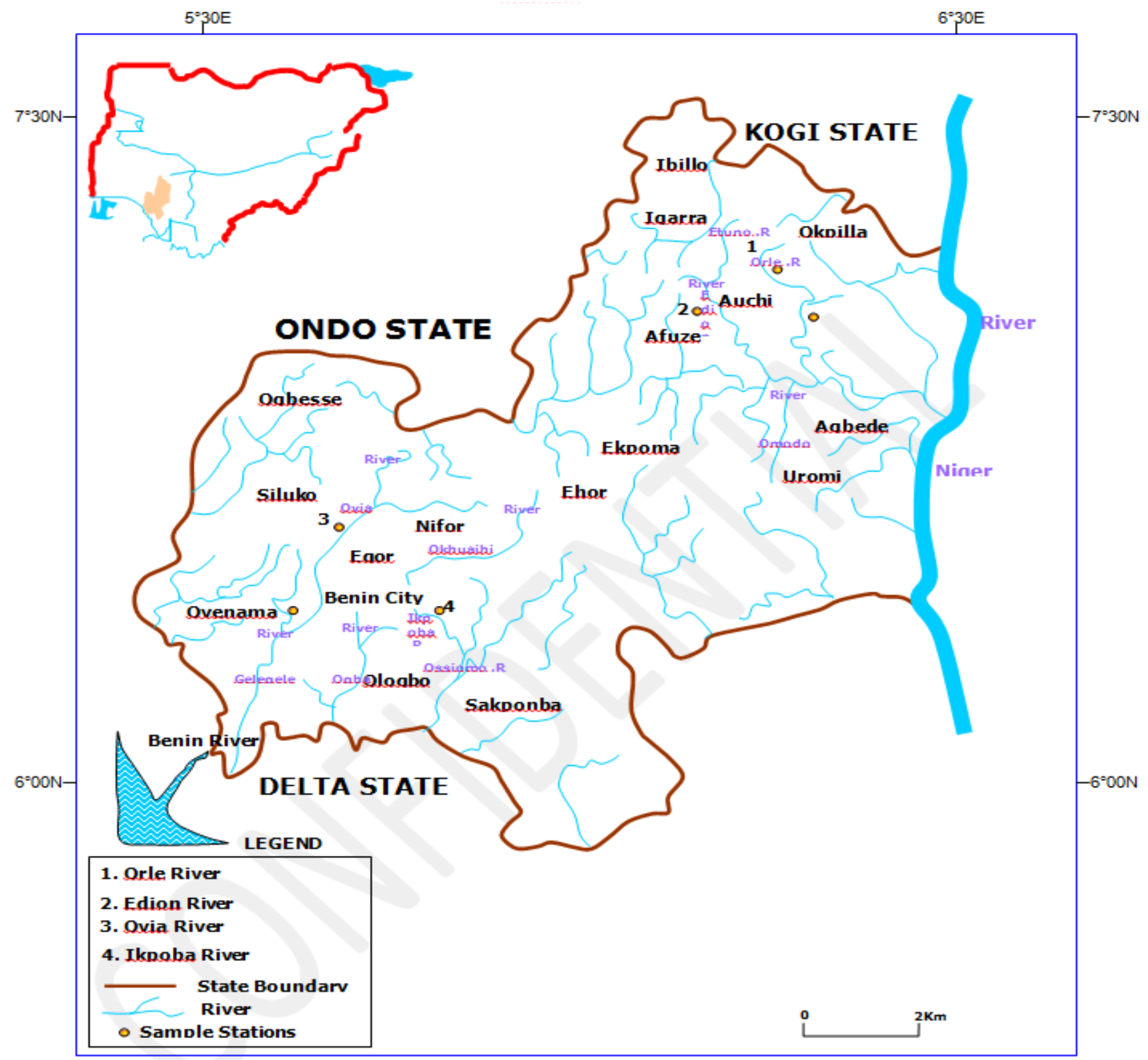

Figure 1: Map of Edo State showing sample stations (modified from Edo State Storm Water Plan, 2010)

\section{Table 1: Classification of Hydropower scheme ([4])}

\begin{tabular}{ll}
\hline Type & Capacity \\
\hline Large Hydropower & $>100 \mathrm{MW}$ \\
Medium Hydropower & $10-100 \mathrm{MW}$ \\
Small hydro & $1-10 \mathrm{MW}$ \\
Mini hydro & $100 \mathrm{~kW}-1 \mathrm{MW}$ \\
Micro Hydro & $5-100 \mathrm{~kW}$ \\
Pico Hydro & $<5 \mathrm{~kW}$ \\
\hline
\end{tabular}

Stream discharge, represents the integrated result of all hydrological and meteorological factors operative in the basin. For practical purposes of discharge analyses, however, total discharge in a stream channel is generally classified as direct runoff and base flow. The direct runoff is that part of discharge which enters the stream promptly after rainfall. It is equal to the sum of the surface runoff and sub-surface runoff plus channel precipitation. The base flow on the other hand is the sustained flow. It is composed of groundwater runoff and delayed surface runoff. In this study however, the term is used after [25] to describe that part of precipitation as well as any other flow contributions which appears in stream surfaces of either perennial or intermittent forms.

Land use/cover and climate are two most important factors influencing hydrological conditions of catchments along with geology and topography. Land use/cover changes have been known to alter the basin hydrograph and have been reported to cause changes in flood frequency $[26,27]$, severity $[28,27]$, base flow 
[29], and annual mean discharge [30]by altering the soil structure and properties. The impact of deforestation on discharge has been studied in detail for many decades [31, 32]. The reports in [33] and [34] indicated that deforestation can increase flood risk, because deforestation causes canopy interception storage, transpiration, and infiltration capacity to decrease.

Climate variability on the other hand can change the peak flows, flow routing time and runoff volumes $[35,36]$.Rainfall characteristics are also important elements discharge generation. Both the intensity and duration of a precipitation event describes the volume and rate in which water is added to the landscape [37].Similarly, the frequency and intensity of a precipitation event influence the moisture present above and below the earth surface. The soil moisture present before a precipitation event is referred to as antecedent soil moisture and influences the ability of water to infiltrate the soil. A reduction in infiltration capacity reduces base flow and increases runoff. The amount of surface water present in a watershed in combination with the local climate has a direct impact on water loss caused by evapotranspiration and is another example of a climatic effect [38]

Other basin factorsinclude: watershed area, slope, size, shape and Drainage basin density. The larger the area of rainfall thresholds, the greater water storage and runoff buffering capacity a watershed has $[39,40]$. [38] and [41] found that flow patterns and velocities of runoff through a landscape are strongly related to the slope and size of the watershed. Smaller watersheds with steeper slopes tend to have faster runoff flows that travel only a short distance before discharging into a lake or stream as there is less time available for infiltration, evapotranspiration, and surface storage. This has an important impact on hydrograph shape. Drainage basin density has been acknowledged as an integrative element in basin in basin morphology [42,43].[44] also observed that water in drainage basins with capacity organised tributaries have a comparatively shorter period of travel and so discharge quicker with greater flood crests. The geology of a particular area defines the interface between ground and surface water in terms of the rate at which surface water translates into subsurface water. This affects the nature of surface drainage and drainage patterns as well as ground water storage $[45,46]$. Since the measurement of basin geological attribute is complicated or sometimes not possible the use of soil-type has enjoyed widespread application as a sole surrogate to or in addition to basin geology as a measure of the basin's lithology [38].

The influence of human actions on discharge generation has been frequently studied in the last decade. Most researchers used either conceptual rainfall-runoff models e.g. $[47,48]$ or distributed physically-based rainfall-runoff models [49] for their investigations. Urbanization has a dramatic influence on runoff and hydrologic response. Urban areas tend to have a larger percent of precipitation forming into runoff and as a result tend to have faster hydrological responses and decreased lag times, increases in peak flow, reductions of base flow and low flows, and decreases in water quality from increased runoff and effluent discharge [50, 51].

\subsubsection{Stream Discharge Measurement}

There are three methods that are commonly adopted for estimating discharge; Discharge estimates based on the area of the drainage basin, precipitation, and the discharge coefficient of each land use pattern, using GIS [52,2, 53,54,55], Discharge estimates based on the water level $(\mathrm{H})$ using the rating curve, also known as the Height-Quantity (H-Q) curve [56,57], discharge estimates as the product of the crosssectional average velocity (Soulis et al., 2016). In this study the third approach was used owing to the absence of historic stream discharge data for the sampled rivers. In spite of the uncertainty associated with this method, it reported to be the main feasible alternative to analyze the hydrologic conditions for regional studies especially in poorly gauged areas [15].

Discharge measurement was carried out for 12 calendar months (From January 2013 to December 2013). Stream discharge measurement method involved the grid point technique, commonly known as velocity-area method [58]. To measure discharge, flow velocity data (V) and area cross section computation (A) were required. A convenient position was selected along the river for the purpose of velocity measurement i.e. a steep gradient as head and a gentle slope as tail. This elevation difference was determined using GPS 12 Garmin model (serial number 36209488) obtained from the National Centre for Energy and Environment of the University of Benin. Two rivers banks connected by a scaled tape were used. Using a graduated meter, depths were taken across the river and recorded. The section 
profile was scaled on paper, and uniformly the grid points were located at lateral vertical points.

In the absence of a flow meter, float was improvised to determine flow velocity. In this study we used a visible buoyant object(Black polythene bags filled with water having the same hydro-dynamic characteristics with river water under investigation).The float was lowered at different points across the river and the number of revolutions (i.e. travel distance over a stretch per time) was recorded. A stop watch was used to determine the time taken for a float to complete a revolution. Elemental flow on each area was given by equation:

$V=\frac{S}{t}$

Where $\mathrm{V}$ is the average stream velocity $(\mathrm{m} / \mathrm{sec})$ :

$s$ is distance of the stretch travelled;

$t$ is the time taken by the float to make the travel.

Velocity was corrected by the equation;

$V_{\text {mean }}=k V_{\text {surface }}$

In (2), $\mathrm{k}$ is a coefficient that generally ranges from 0.8 for rough beds to 0.9 for smooth beds ( 0.85 was used in this study). Three test runs were made to obtain reliable results in each case. The cross-sectional area of the channel at the measuring site was estimated as the product of the measured channel width and the mean stream depth and represented by the equation: $A=\left(\sum d / n\right) w$

In (3), A is the cross- sectional area of the stream $\left(\mathrm{m}^{2}\right)$; $\mathrm{n}$ is the number of points where the stream depth is taken: $d$; is the depth of the of stream at points $i(i=1,2------, n) ; w$ is the width of the stream channel at the measurement point. Channel width was measured by the use of a steel tape while depth at different points graduated staff gauge. Measurements of Depth and width were done three times at different revolutions and the average recorded in line with international practices.

Simultaneous measurement of discharge $(Q)$ was then determined based on the fact that $Q$, is directly proportional to the product of the average stream velocity, $\mathrm{V}$. and the cross sectional area of the river channel, $A$, at the point of measurement as represented by

$\mathrm{Q}=\mathrm{AV}$

Here, $Q$ is the stream flow rate $\left(\mathrm{m}^{3} / \mathrm{sec}\right)$; $\mathrm{A}$ is the cross -sectional area of the channel $\left(\mathrm{m}^{2}\right) ; \mathrm{V}$ is the average stream velocity $(\mathrm{m} / \mathrm{sec})$ [7]. Plates $1-2$ below illustrate how river discharge measurements were conducted.

\subsection{Estimating gross hydropower potential (GHP)}

Gross hydropower potentials (GHP) is the theoretical optimum limits of hydroelectricity production (HEP) of any river basin which represents the potential for possible feasible fall and low within the basin [59]. GHP was determined using model developed by [60]. The model is based on the fact that GHP is proportional to the product of gross head and discharge which was determined from equation below.

$$
P=\operatorname{epg} Q H
$$

Here GHP or $\mathrm{P}$ is power (Watts), e is the overall efficiency (\%)for which the typical value of 0.9 was used in this study, $\rho$ is the density of water $(1,000$ $\left.\mathrm{kg} / \mathrm{m}^{3}\right)$, $\mathrm{g}$ is the acceleration due to gravity $\left(9.81 \mathrm{~m} / \mathrm{s}^{2}\right)$ and $\mathrm{Q}$ is the water discharge expected to pass through the turbine $\left(\mathrm{m}^{3} / \mathrm{s}\right)$, and $\mathrm{H}$ is the gross head $(\mathrm{m})$.

\subsubsection{Flow Duration Curve (FDC) Method}

FDC was used to estimate the available amount of water that can keep up the stream flow and the variability of the amount of the water in the catchment as has been applied by [61 - 63] in their works.
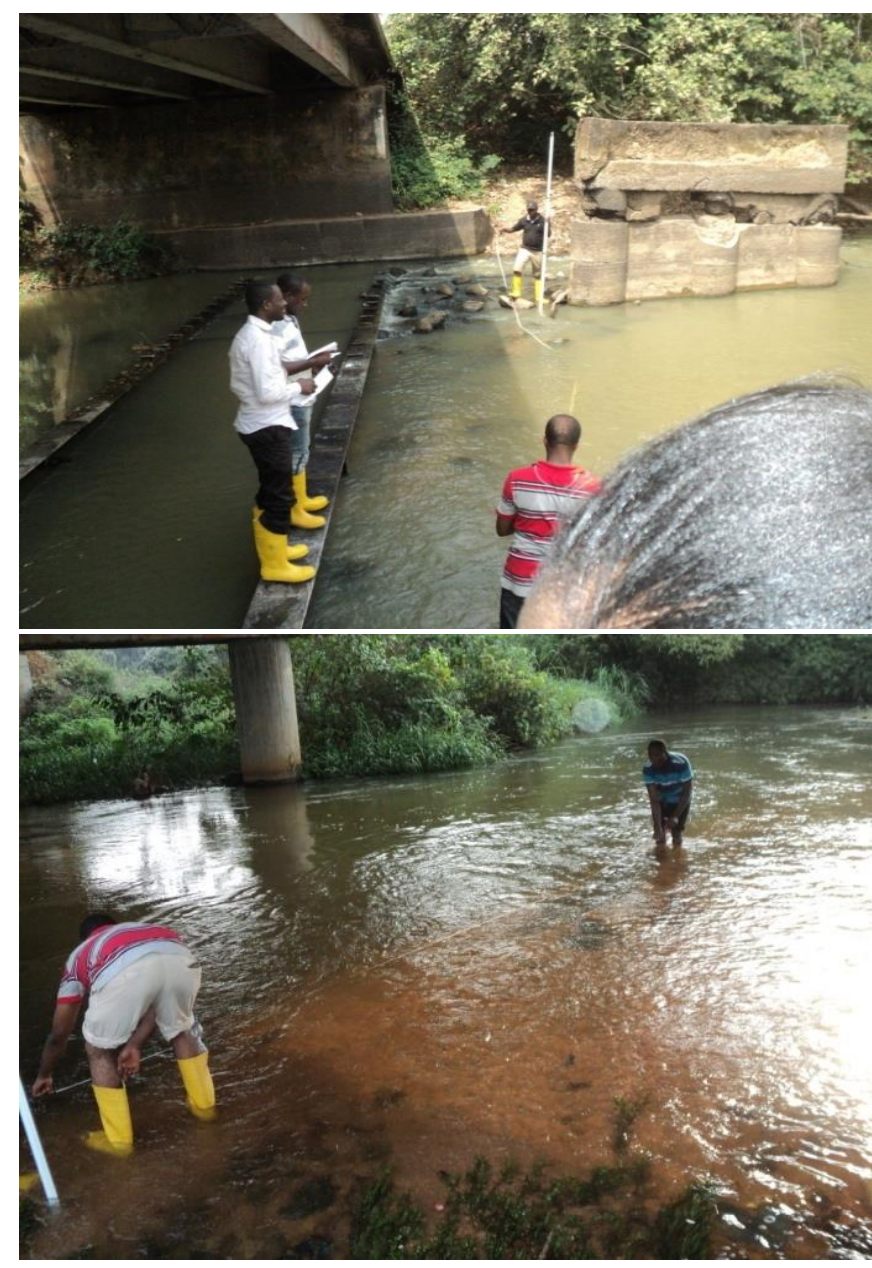

Plates.1 \& 2: Measuring discharge of Ovia River 
In this study, the graphical approach was adopted to construct flow duration curves of rivers using measured discharge data. Several authors have used this procedure for generating FDC's at ungauged river basins $[64,65]$.The probability of exceedance (Pei) was estimated using the following equation 7 [166]:

$P e i=100\left(\frac{m}{n+1}\right)$

Here, $P e i$ is the probability of a given flow that will be equalled or exceeded, $m$ is the rank number when daily or monthly flows are arranged in descending order and, $\mathrm{n}$ is the total number of observation.

\subsubsection{Statistical Analysis.}

Parametric statistical tools were adopted. These include Pearson's product moment correlation " $r$ " and Simple Linear regression. The Pearson product moment correlation was used to establish the degree of association between discharge and power yield, while deterministic relationship between discharge and power yield was established using linear regression. All analysis were performed using the statistical package for social sciences (SPSS), version 16.0 and the excel Analysis tool Pak.

\section{RESULTS AND DISCUSSION}

The seasonal patterns of measured stream discharges for the sample Rivers are presented as Figures. 2-5.In all the sampled rivers, there were noticeable trends in seasonal discharge patterns. Stream discharge was generally observed to be at peak in September, except for Orlie River where stream discharge peak was recorded in August. These variations in peak discharge suggest time difference in rainfall peak and recession periods in the rivers. The average discharge volumes of Sample Rivers are $93.01 \mathrm{~m}^{3}$, $48.48 \mathrm{~m}^{3}, 29.36 \mathrm{~m}^{3}$ and $18.77 \mathrm{~m}^{3}$ for Rivers Ovia, Ikpoba, Orlie and Edion respectively (Table 2).

On annual basis, highest discharge volume was recorded in Ovia River with a discharge volume of $1116.12 \mathrm{~m}^{3}$ followed by Ikpoba River $\left(581.76 \mathrm{~m}^{3}\right)$. In Rivers Orlie and Edion annual discharge volumes were recorded as $352.33 \mathrm{~m}^{3}$ and $225.32 \mathrm{~m}^{3}$ respectively.

The variation in stream discharge amounts may be attributed to the influences of basin factors including rainfall amounts, basin area, topographic and linear characteristics which affect discharge generation processes and flow patterns. The significance of drainage basin area in discharge generation has formed important discussion in hydrological studies. Thus, it is expected that the larger the area of rainfall thresholds, the greater water storage and runoff buffering capacity a watershed as was seen in the case of discharge volume of Ovia River when compared to discharge generated from River Edion.

More so, basins with steeper slopes tend to have faster runoff flows which travel only a short distance before discharging into a stream. This has an important impact on hydrologic response. The faster the water flows across the land, the less time is available for infiltration, evapotranspiration, and surface storage [41].

Table 2: Descriptive Statistics of Discharge Patterns

\begin{tabular}{lllllll}
\hline River & $\begin{array}{c}\text { Annual Discharge } \\
\mathrm{m}^{3}\end{array}$ & Mean & SD & SE & Median & Variance \\
\hline Ovia & 1116.12 & 93.01 & 154.6538 & 44.6447 & 25.865 & 23917.79 \\
Ikpoba & 581.76 & 48.48 & 54.63761 & 15.77252 & 26.94 & 2985.268 \\
Orlie & 352.33 & 29.36083 & 39.69954 & 11.46027 & 3.105 & 1576.053 \\
Edion & 225.32 & 18.77667 & 20.57933 & 5.94074 & 5.045 & 423.5087 \\
\hline
\end{tabular}

SD: Standard Deviation, SE: Standard error

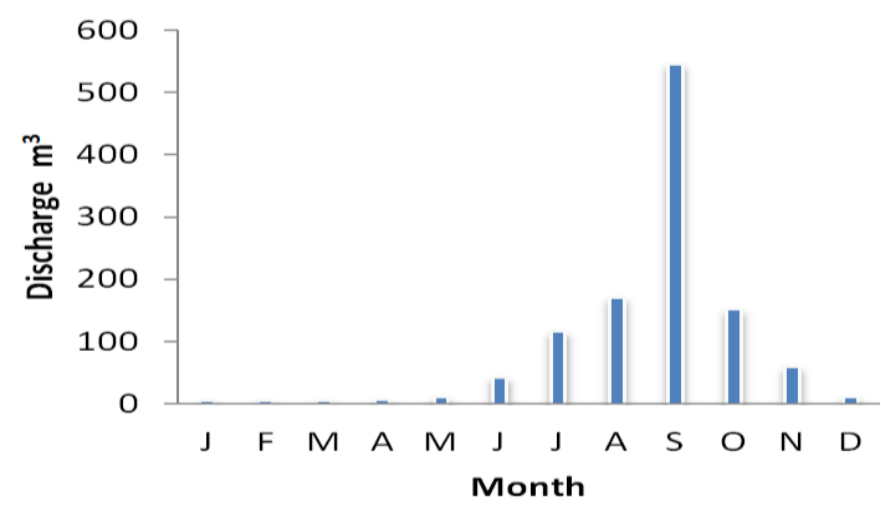

Figure 2: Seasonal Pattern of Discharge in Orlie Riber

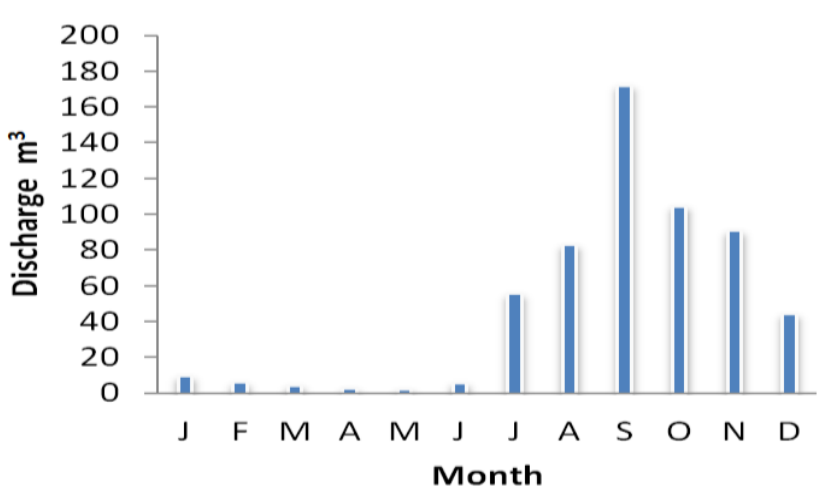

Figure 3: Seasonal pattern of discharge in Ikpoba 


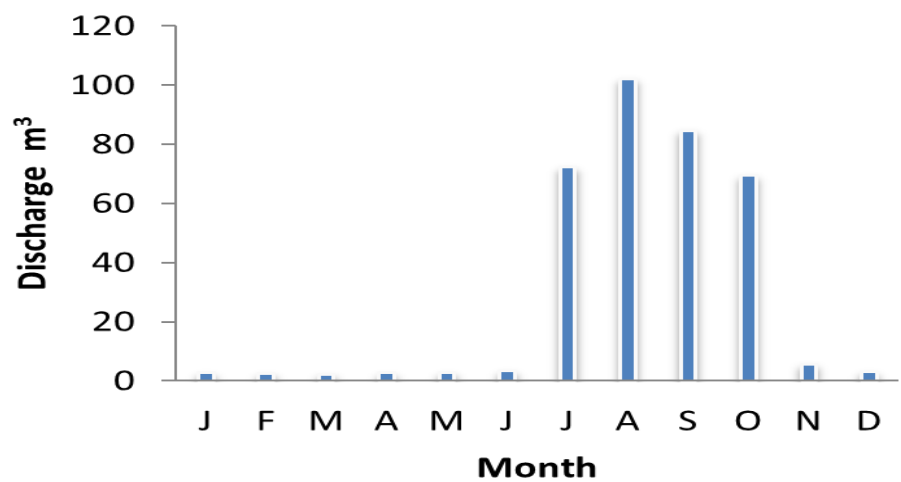

Figure 4: Seasonal Pattern of Discarge in Orlie River

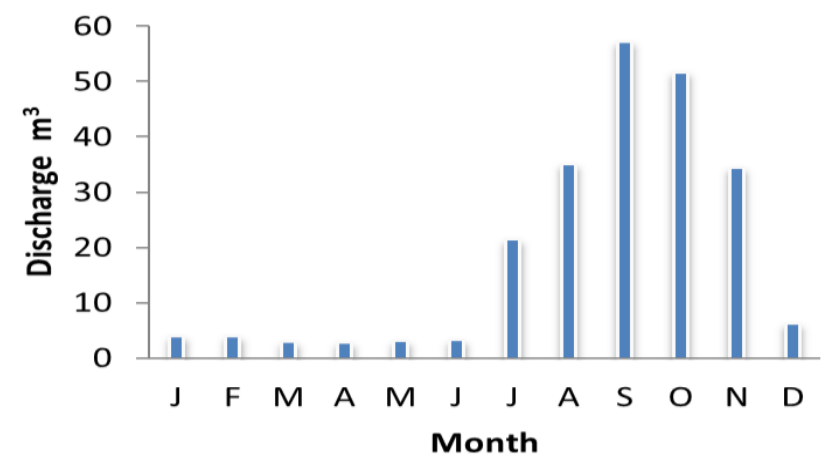

Figure 5: Seasonal pattern of discharge in Eion River
This can increase peak stream discharge, while decreasing a stream's lag time. Although the morphometry of the river basins under investigation is beyond the scope of this study, discharge volumes as measured in this study provided indirect information on the morphometry of these rivers.

The Flow Duration Curves as presented in Figures 6 9 , identify the intervals which can be used as general indicator of hydrological conditions that favour a small hydropower projects in the sampled Rivers. The graphical representations show the relationship between the time excess probability represented as Xaxis (also known as duration or frequency of occurrence) and the monthly discharge quantity corresponding to the probability as Y-axis. Streamflow data collected during field survey was used to plot the Flow Duration Curve. Flow duration intervals are expressed as percentage of exceedance, with zero corresponding to the highest stream discharge in the record (i.e., flood conditions) and 100 to the lowest (i.e., drought conditions). In Figure 6, the point, $(\mathrm{p}, \mathrm{q})$ $=\left(7.7 \%, 544.8 \mathrm{~m}^{3}\right)$ on the graph of monthly flows indicate that during the period of study (12 months) highest monthly discharge exceeded $544.8 \mathrm{~m}^{3} / \mathrm{sec}$ only less than 10 times (7.7\%) in Ovia River and so on down to low flow period. In Ikpoba River, highest discharge volume exceeded $172 \mathrm{~m}^{3} / \mathrm{sec}$ only $7.7 \%$ (Figure 7), in Orlie highest exceedance volumes are $102.1 \mathrm{~m}^{3} / \mathrm{sec}, 7.7 \%$ (Orlie River) (Figure 8) and $57.1 \mathrm{~m}^{3} / \mathrm{sec}$ was exceeded $7.7 \%$ in Edion River (Figure 9).

In addition to providing information on the percentage of time (duration) monthly streamflow is exceeded over a period for each particular river basin, the FDC subdivided each hydrological condition into high flows (0-15\%), another for moist conditions (15$40 \%)$, one covering mid-range flows (40-60\%), another for dry conditions (60-85\%), and one representing low flows (85-100\%) as illustrated in Figures 6 - 9. From the Figures, the ranges $0-15 \%$ corresponds to rainfall peak, 15-40\%; 40-60\% represent adequate to average water supply in the rivers, while $60-85 \%$ and $85-100 \%$ indicate dry and low flows respectively.

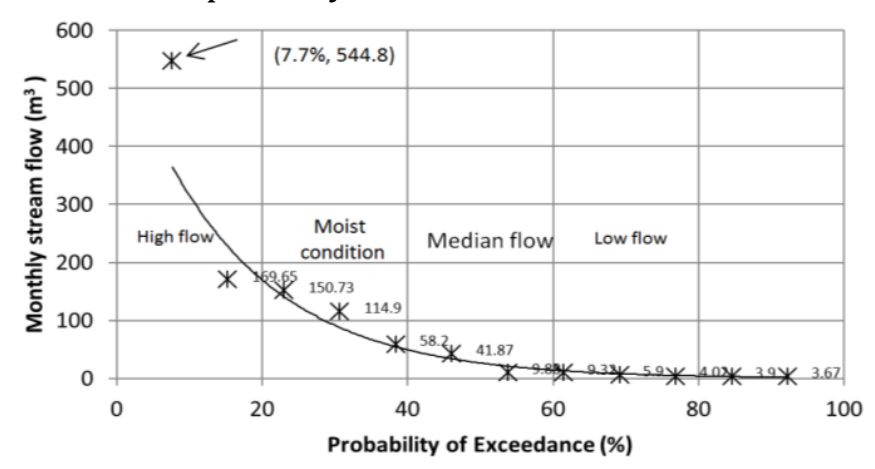

Figure 6: Flow duration curve of River Ovia

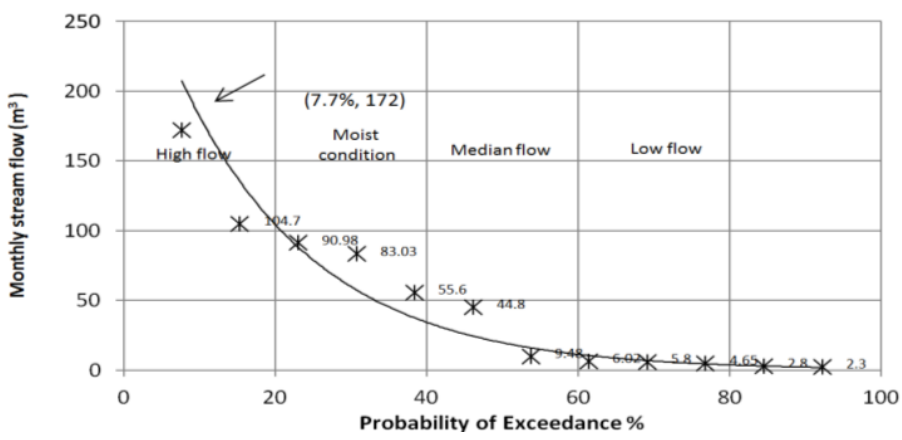

Figure 7: Flow duration curve of River Ikpoba

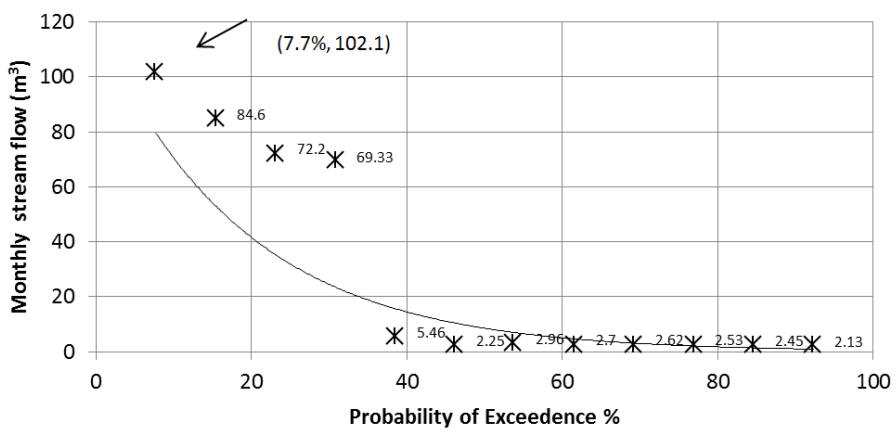

Figure 8: Flow duration curve of River Orlie 


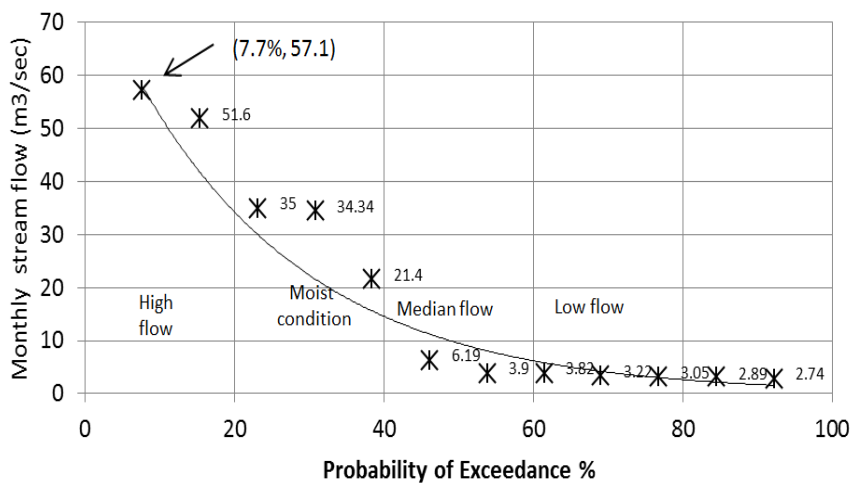

Figure 9: Flow duration curve of River Edion

These periods also present the proportion of flow contributed from ground water storage and flow

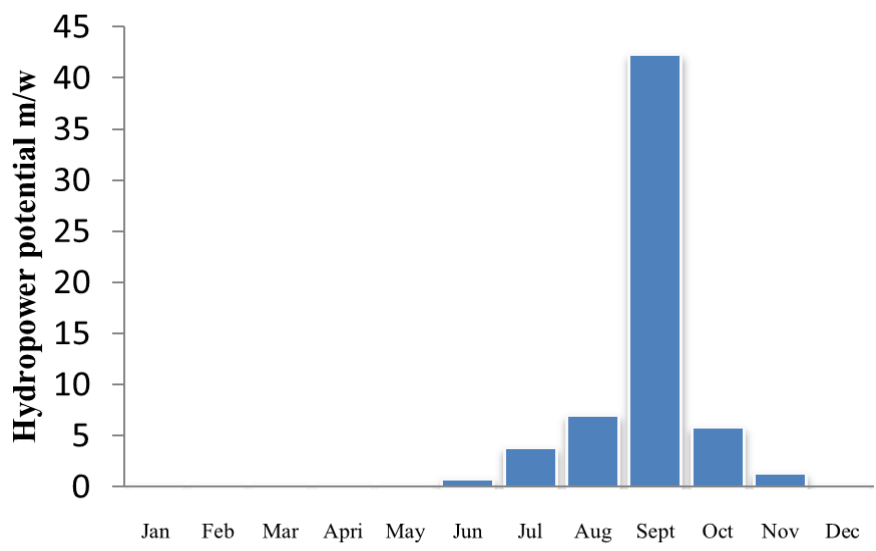

Month

Figure 10: Seasonal fluctuation in Hydropower potential of Ovia River

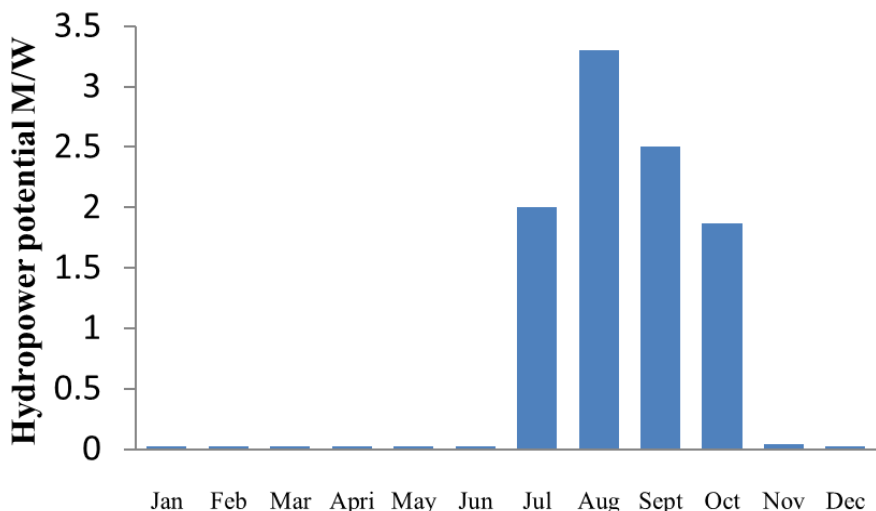

Month

Figure 12: Seasonal fluctuation in Hydropower potential of Orlie River recession due to rainfall cessation $(60-85 \%$ and $85-$ $100 \%)$.

The technical power potentials from our sample Rivers are presented as Figures.10- 13. Technical hydropower potentials in this study is defined as the energy that is potentially available and/or is harnessable from stream flow $\left(\mathrm{m}^{3}\right)$ regardless of economic, social and other restrictions/influences arising from basin physiographic characteristics [67]. Descriptive statistics of observed power yields from sample rivers are shown in Table 3, while Table 4 is the summary of harnessable energy by elevation.

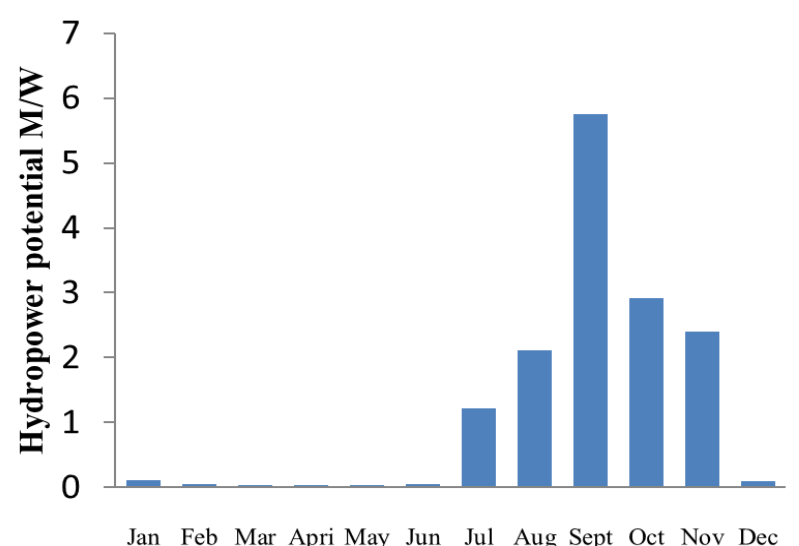

Month

Figure 11: Seasonal fluctuation in Hydropower potential of Ikpoba River

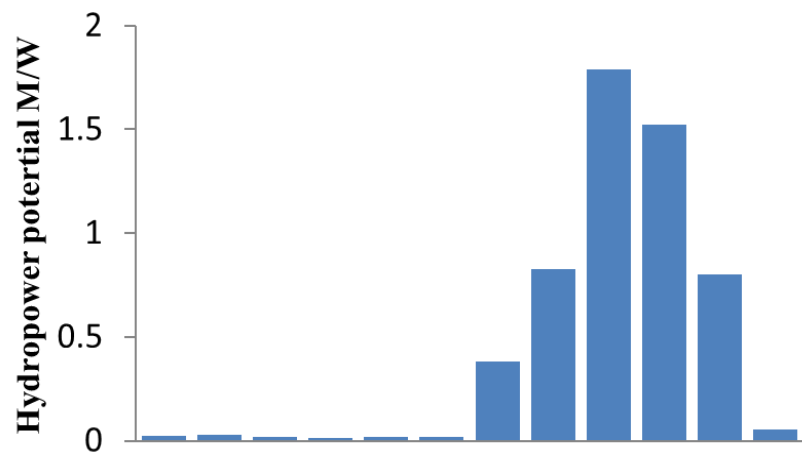

Jan Feb Mar Apri May Jun Jul Aug Sept Oct Nov Dec

\section{Month}

Figure 13: Seasonal fluctuation in Hydropower potential of Edion River

Table 3 Descriptive Statistics of observed Power Yield

\begin{tabular}{lllllll}
\hline River & Total yield MW & Mean & SD & SE & Median & Variance \\
\hline Ovia & 61.6189 & 5.134908 & 11.99035 & 3.461316 & 0.4539 & 143.7685 \\
Ikpoba & 14.7868 & 1.232233 & 1.786953 & 0.515849 & 0.0983 & 3.193203 \\
Orlie & 9.819 & 0.81825 & 1.227717 & 0.354411 & 0.0195 & 1.507289 \\
Edion & 5.4956 & 0.457967 & 0.638119 & 0.184209 & 0.04 & 0.407195 \\
\hline
\end{tabular}


Hydrological AsSESSments of Some Rivers in Edo State, Nigeria for SMAll-Scale Hydropower.... C. N. Emeribe, et al.

Table 4: Harness-able Energy by Height and discharge Volume

\begin{tabular}{ccccccccccccc}
\hline & \multicolumn{3}{c}{ Ovia River } & \multicolumn{4}{c}{ Ikpoba River } & \multicolumn{3}{c}{ Orlie Rivers } & \multicolumn{3}{c}{ River Edion } \\
\hline Month & $\begin{array}{c}\mathrm{H} \\
(\mathrm{m})\end{array}$ & $\mathrm{Q}\left(\mathrm{m}^{3}\right)$ & $\begin{array}{c}\text { Power } \\
\mathrm{MW}\end{array}$ & $\mathrm{H}(\mathrm{m})$ & $\begin{array}{c}\mathrm{Q} \\
\left(\mathrm{m}^{3}\right)\end{array}$ & $\begin{array}{c}\text { Power } \\
\mathrm{MW}\end{array}$ & $\mathrm{H}(\mathrm{m})$ & $\mathrm{Q}\left(\mathrm{m}^{3}\right)$ & $\begin{array}{c}\text { Power } \\
\mathrm{MW}\end{array}$ & $\begin{array}{c}\mathrm{H}(\mathrm{m}) \\
\mathrm{Q} \\
\left(\mathrm{m}^{3}\right)\end{array}$ & $\begin{array}{c}\text { Power } \\
\mathrm{MW}\end{array}$ \\
\hline Jan & 0.63 & 4.02 & 0.022 & 1.29 & 9.48 & 0.107 & 0.65 & 2.62 & 0.015 & 0.75 & 3.89 & 0.025 \\
Feb & 0.60 & 3.67 & 0.019 & 1.09 & 6.02 & 0.058 & 0.63 & 2.45 & 0.014 & 0.76 & 3.9 & 0.026 \\
Mar & 0.62 & 3.9 & 0.021 & 0.99 & 4.45 & 0.041 & 0.59 & 2.13 & 0.011 & 0.62 & 2.89 & 0.016 \\
Apri & 0.72 & 5.2 & 0.033 & 0.82 & 2.8 & 0.02 & 0.64 & 2.53 & 0.014 & 0.66 & 2.74 & 0.015 \\
May & 1.02 & 9.86 & 0.088 & 0.76 & 2.3 & 0.015 & 0.66 & 2.7 & 0.016 & 0.68 & 3.05 & 0.018 \\
Jun & 2.22 & 41.87 & 0.8198 & 1.08 & 5.8 & 0.055 & 0.72 & 3.25 & 0.021 & 3.02 & 3.22 & 0.019 \\
July & 3.82 & 114.9 & 3.871 & 2.49 & 55.6 & 1.221 & 3.15 & 72.2 & 2.006 & 2.68 & 21.4 & 0.3813 \\
Aug & 4.71 & 169.65 & 7.047 & 2.89 & 83.03 & 2.1164 & 3.66 & 102.1 & 3.296 & 3.55 & 35 & 0.8273 \\
Sept & 8.82 & 544.8 & 42.381 & 3.79 & 172.2 & 5.756 & 3.35 & 84.6 & 2.499 & 3.35 & 57.1 & 1.787 \\
Oct & 4.42 & 150.73 & 5.8761 & 3.15 & 104.7 & 2.9088 & 3.05 & 69.33 & 1.865 & 2.65 & 51.6 & 1.524 \\
Nov & 2.65 & 58.2 & 1.36 & 2.99 & 90.98 & 2.399 & 0.92 & 5.46 & 0.044 & 1.9 & 34.34 & 0.803 \\
Dec & 0.99 & 9.32 & 0.081 & 2.29 & 44.4 & 0.0896 & 0.69 & 2.96 & 0.018 & 0.99 & 6.19 & 0.054 \\
\hline
\end{tabular}

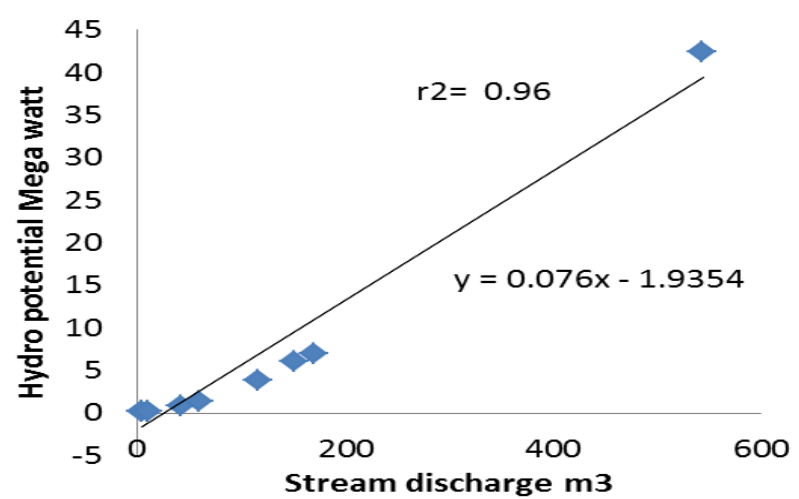

Figure 14: Deterministic Relationship between Discharge and Hydropower potential of Ovia River

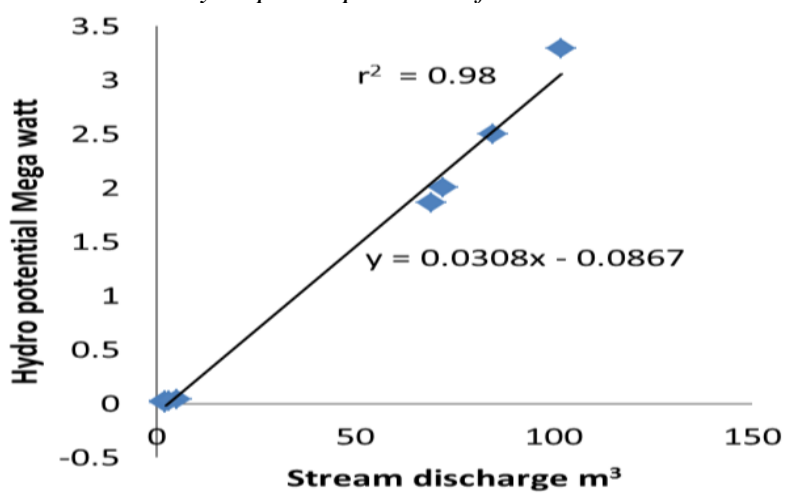

Figure 16: Deterministic Relationship between Discharge and Hydropower potential of Orlie River

Power potentials in all the sample Rivers showed marked fluctuation in response to seasonal discharge patterns. Generally, highest monthly hydropower yields were recorded in September for Ovia, Ikpoba and Edion Rivers and in August for Orlie River (Figures. 10 - 13). On annual basis, Ovia River, recorded the highest power yield of $61.619 \mathrm{MW}$ (suggesting the Ovia river maybe suitable for a Medium hydro). Highest monthly power yield of 42.381 mw was recorded in September, followed by August (7.047MW). Lowest power yield of 0.019MW

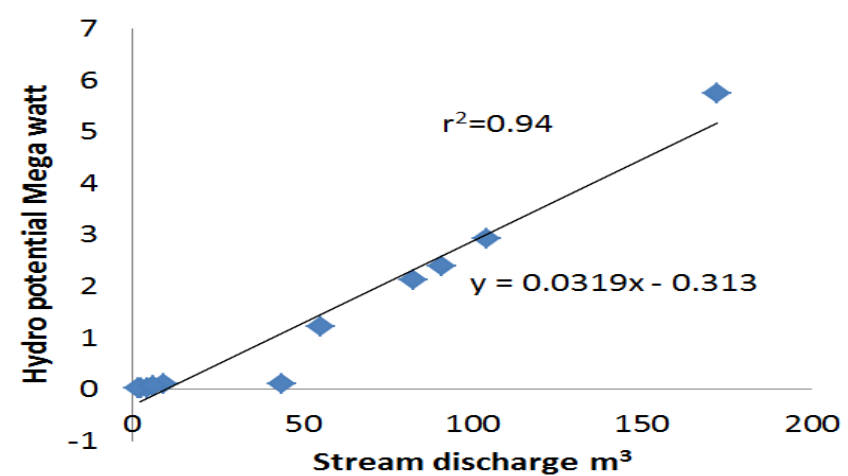

Figure 15: Deterministic Relationship between Discharge and

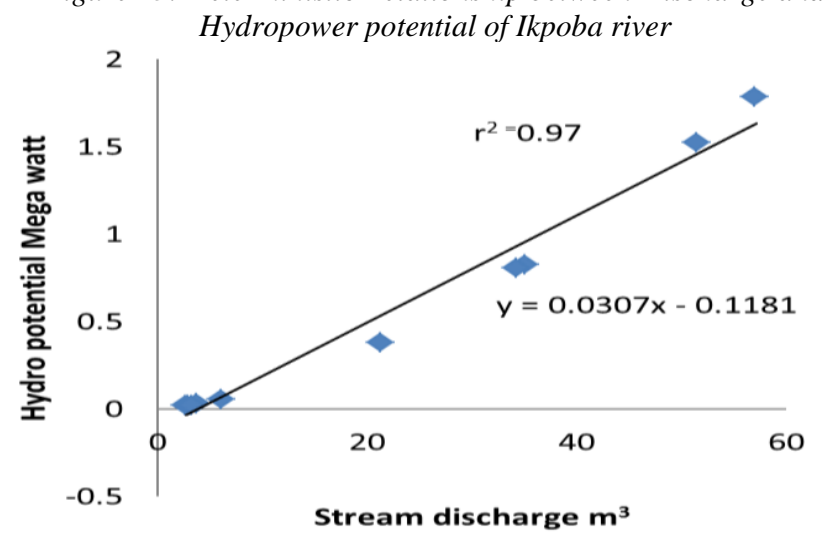

Figure 17: Deterministic Relationship between Discharge and Hydropower potential of Edion river

was recorded in February (Figure 10). In Ikpoba River annual hydropower yield was recorded as 14.78MW, lowest power yield of $0.02 \mathrm{MW}$ was recorded in April while highest yield of 5.76 was recoreded in september (Figure 11). River Orlie recoreded an annual hydropower yield of $9.819 \mathrm{MW}$, with August having the highest power yield of 3.296MW. Other significant hydropower yield values were recorded in September and July ( Figure 12). Edion River has an annual power yield of 5.49MW. Lowest yield in this river was recorded in April 
(Figure 13). The annual power yield distribution as observed, reflects the ecological patterns in Edo State. Rivers ovia and Ikpoba falls into the rainforest zone, while Orlie and Edion, derived savannah zone.

A determinstic relationship between observed discharge and power potentials within our sample Rivers yielded positive relationship in all the rivers (Figures 14-17). This was achieved using the Pearson Product Correlation Analysis " $r$ ".

In Ovia River, it was observed that $96 \%$ variation in power yield is explained by stream discharge (Figure 14). In Ikpoba River the percentage of deterministic relationship was recorded as $94 \%$ (Figure 15). In Orlie River the determinable relationship was recorded as $98 \%$ (Figure 16) and $97 \%$ in Edion River (Figure 17).

\section{CONCLUSION AND RECOMMENDATIONS}

This study has investigated the potential for utilizing small-scale hydropower for rural electrification schemes in Edo State. Four Rivers were selected randomly for study. These are Rivers Ovia, Ikpoba, Orlie and Edion. Findings from this study showed that, on annual basis however, Ovia River, recorded the highest power yield and maybe classified as sutiable for Medium hydro site while Rivers Ikpoba, Orlie and Edion are suitable for small-scale hydropower project. Highest monthly power yield was recoreded in september, followed by August. Lowest power yield was recorded in February. In Ikpoba River lowest power yield was recorded in April while highest yield was recoreded in september. River Orlie recoreded recorded peak yield August while other significant hydropower yield values were recorded in September and July. Edion River recorded lowest yield April. In Ovia River, it was observed that $96 \%$ variation in power yield is explianed flow availability. In Ikpoba River the percentage of deterministic relationship was recorded as 94\%; $98 \%$ and $97 \%$ in Rivers Orlie and Edion. Results of Flow duration curve (FDC) revealed that a extreme high monthly discharge volume of $544.8 \mathrm{~m}^{3}$ in Ovia river, $172 \mathrm{~m}^{3}$ in Ikpoba river, $102.1 \mathrm{~m}^{3}$ in Orlie and $57.1 \mathrm{~m}^{3}$ in Edion have dependability percentages of less than $10 \%$. Notwithstanding the hydrological conditions of these rivers can be categorized as adequate (15\%-40\%) to average moisture conditions (40\%-60\%).

While this study is limited to stream flow analysis there is need for a more comprehensive appraisal technical, socio-economic viability of small scale hydropower development in the rivers investigated.
Such investigation will include analysis of basin morphometry for the purpose of understanding the influence of basin characteristics on the power potentials of studied rivers. Lastly, the outcomes of this study may serve as an in no small measure as a guide to government and hydropower developers on locating specific rivers in Edo State for obtaining reasonable yield at a glance. Secondly, discharge and power yield results provided in this study will provide regional views of hydropower potentials according to ecological zones that characterize Edo State.

\section{ACKNOWLEDGEMENT}

This project was funded by the National Centre for Energy and Environment, an agency of the Energy Commission of Nigeria (ECN), University of Benin. The authors would like to thank the Centre's Technical Advisory Committee (TAC) and Management for approving this study. The constructive remarks by the Director, National Centre for Energy and Environment, Prof. Lawrence I. Ezemonye were invaluable towards the successful completion of this work. We gratefully acknowledge the Centre's Administrative Secretary and the Finance officer for their meaningful suggestions at various stages of this project.

\section{REFERENCES}

[1] World Development Indicators. "Little Green Data Book"2011.

[2] Kusre, B. C. Baruah, D. C. Bordoloi, P. K and. Patra, S. C "Assessment of hydropower potential using GIS and hydrological modeling technique in Kopili River basin in Assam India ," Appl. Energy, vol. 87, no. 1, pp. 298-309, 2010.

[3] Spänhoff B. Current status and future prospects of hydropower in Saxony (Germany) compared to trends in Germany, the European Union and the world. Renewable Sustainable Energy Rev ;30:51825. 2014.

[4] Anderson, T., Doig A., Khennas S and Rees, D. "A Handbook for sustainable energy development," London: Intermediate Technology Cop 1999.

[5] Maher, P and Smith, N. Pico Hydro for village power: A practical manual for schemes up tp $5 \mathrm{kw}$ in Hilly areas,. Intermediate Tec. Publications, London 2001.

[6] Dursun B, Gokcol C. The role of hydroelectric power and contribution of small hydropower plants for sustainable development in Turkey. Renewable Energy; 36:1227-35. 2011. 
[7] Xingang Z, Lu L, Xiaomeng L, Jieyu W, Pingkuo L.A critical-analysis on the development of China hydropower. Renewable Energy; 44:1-6. 2012.

[8] Chang X ,Liu X ,Zhou W .Hydropower in China at present and its further development. Energy 2010;35: 4400-6.

[9] Osmani A, Zhang J, Gonela V, Awudu .Electricity generation from renewables in the United States :resource potential, current usage, technical status, challenges, strategies, policies, and future directions. Renew. Sustain. Energy Rev. 24:454-72. 2013.

[10] Kosnik L. "The potential for small scale hydropower development in the US. Energy Policy 2010; 38:5512-9.

[11] Kaunda C. S "Energy situation, potential and application status of small-scale hydropower systems in Malawi". Renewable Sustainable Energy Rev;26: 1-19. 2013

[12] ESHA/IT-Power." Small Hydropower for Developing Countries", European Small Hydropower Association. Belgium. www.esha.be. 2006.

[13] Fraenkel P., Paish O., Bokalders V., Harvey, A and Edwards, R. Micro-Hydro Power. A guide for development workers, London: Immediate Technology Publications in associated with the Stockholm environment Institute 1991.

[14] IEA (International Energy Agency). Benign Energy? The Environmental Implications of Renewables, Paris: OECD 1998.

[15] Soulis, K. X, Manolakos D., and Anagnostopoulos J, "Development of a geo-information system embedding a spatially distributed hydrological model for the preliminary assessment of the hydropower potential of historical hydro sites in poorly gauged areas," Renew. Energy, vol. 92, pp. 222-232, 2016.

[16] Seibert J and Beven, K. J Gauging the ungauged basin: how many discharge measurements are needed? Hydrol. Earth Syst. Sci., 13, 883-892. 2009.

[17] Negrel, J. Kosuth, P.and Bercher N. "Estimating river discharge from earth observation measurements of river surface hydraulic variables". Hydrol. Earth Syst. Sci., 15, 2049-2058. 2011.

[18] Dike, B.U. and Nwachukwu, B.A. "Analysis of Nigerian Hydro-meteorological Data. Nigerian Journal of Technology," Vol. 22, No. 1,, pp:29-38. 2003.

[19] Ezemonye M.N and Emeribe C.N "Appraisal of the Hydrological Potential of Ungauged Basin Using Morphometric Parameters," Ethiopian Journal of
Environmental Studies and Management Vol. 6 No.4 2013.

[20] Abiodun, A. A. "Water resources projects in Nigeria and the hydrological data employed in their planning and development". Proceedings Symposium on Design of Water Resources Projects with Inadequate Data. Madrid, pp. 21-32. 1973.

[21] Nigerian Meteorological service NIMET, Rainfall and temperature data for Benin City synoptic station 2010-2012, Archives of the Nigerian Meteorological service pp13. 2007.

[22] National Centre for Energy and Environment "Rainfall and temperature data over Benin City, archives of the National Centre for Energy and Environment 2010-2012, pp 12-18, 2010.

[23] Atedhor, G O. Odjugo P.A and Uriri A.E "Changing rainfall and anthropogenic-induced flooding: Impacts and adaptation strategies in Benin City, Nigeria Journal of Geography and Regional Planning Vol. 4(1), pp.42-52, 2010.

[24] Ward R.C and Robinson, M "Principles of Hydrology". McGraw-Hill Companies, London 1990.

[25] Chow, V. T. "Runoff" in Chow, V.T. (ed.), Handbook of Applied Hydrology, Section. 14.McGraw-Hill, New York 1964

[26] Brath, A., Montanari, A. and Moretti, G. "Assessing the effect on flood frequency of land use change via hydrological simulation with uncertainty, Journal of Hydrology, 324,; pp141-153. 2006.

[27] Tollan, A. "Land-use change and floods": What do we need most, research or management? 8 ed.: IWA Publishing 2002.

[28] De Roo, A., Odijk, M., Schmuck, G., Koster, E. and Lucieer, A.. Assessing the effects of land use changes on floods in the meuse and oder catchment. Physics and Chemistry of the Earth, Part B: Hydrology, Oceans and Atmosphere, 26, , 593-599. 2001.

[29] Wang, G., Zhang, Y., Liu, G. \& Chen, L. "Impact of land-use change on hydrological processes in the Maying River basin, China. Science in China, Series D: Earth Sciences, 49, 1098-1110. 2006.

[30] Costa, M. H., Botta, A. \& Cardille, J. A. "Effects of large-scale changes in land cover on the discharge of the Tocantins River, Southeastern Amazonia. Journal of Hydrology, 283, 206-217. 2003

[31] Peters, N. E., and Seth R. "Effects of Urbanization on Streamflow in the Atlanta area (Georgia, USA): a Comparative Hydrological Approach." Hydrological Processes 15: 1441-1457, 2001.

[32] Frazier, P., and Page, K. "Water Body Detection and Delineation With Landsat TM 
data." Photogrammetic Engineering and Remote Sensing 66, 1461-1467. 2000.

[33] Laurance, W. F."Forests and floods", Nature, 449, , 409-410. 2007.

[34] Bradshaw, C. J. A.,. Sodhi N. S,. Peh K. S.-H, and. Brook B. W "Global evidence that deforestation amplifies flood risk and severity in the developing world," Global Change Biol., 13, , 1-17 2007.

[35] Changnon, S. A. and Demissie, M "Detection of changes in streamflow and floods resulting from climate fluctuations and land use-drainage changes." Climatic Change, 32, 411-421. 1996.

[36] Prowse, T., Beltaos, S., Gardner, J., Gibson, J., Granger, R., Leconte, R., Peters, D., Pietroniro, A., Romolo, L. and Toth, B "Climate Change, Flow Regulation and Land-Use Effects on the Hydrology of the PeaceAthabasca-Slave System; Findings from the Northern Rivers Ecosystem Initiative" Environmental Monitoring and Assessment, 113, 167-197. 2006.

[37] Goel, N. K.. Kurothe, R. S. Mathur, B.S. Vogel R.M “A derived flood frequency distribution for correlated rainfall intensity and duration Journal of Hydrology 228, 56-67. 2000.

[38] Berger, K.P., and. Entekhabi D "Basin Hydrologic Response Relation to Distributed Physiographic Descriptors and Climate." Journal of Hydrology 247: 169-182. 2001.

[39]. Bielders, C. L., Evrard, O., Vandaele, K., and B. V. Wesemael "A Grassed Waterway and Earthen Dams to Control Muddy Floods From a Cultivated Catchment of the Belgian Loess belt." Geomorphology 100: 419-428. 2008,

[40] Haiming, Lu,Yin Chenquing, Wang, Weidong, and Baoqing Shan. "A comparative Study of Nutrient Transfer via Surface Runoff From two Small Agricultural Catchments in North China." Environmental Geology 52: 1549-1558. 2007.

[41] Bo-Jie, Fu, Qing-hua, Meng, Qiu-ju, Zhang, Wen-wu, Zhao, and Fu Bo-jie. 2004. "Effects of Land-use Pattern Change on Rainfall-Runoff and RunoffSediment relations: A Case Study in Zichang Watershed of the Loess Plateau of China." Journal of Environmental Sciences 16(3): 436-442.

[42] Bowling, L. C., P. Storck and D.P. Lettenmaier "Hydrologic effects of logging in western Washington, United States: Water Resources Research," vol. 36 no. 11, 2000 p. 3223-3240.

[43] Yildiz S "An Investigation of the E ect of Drainage Density on Hydrologic Response." Turkish J. Eng. Env. Sci.28, , 85-94. 2004.
[44] Gregory, K. J. and Walling, D.E. 'Drainage Basin Form and Processes: A Geographical Approach. Edward Arnold London 1973.

[45] Alkali, G. A. "River-Aquifer Interaction in the Middle Yobe River Basin, North-East Nigeria”. Institute of WATER resources Research, Occasional Paper, Cranfield University, Silsoe Campus 1995.

[46] Carter, R. C. and Alhassan "Groundwater soil and development in the basins of the Manga grassland, NE Nigeria". Proceedings, Symposium on Hydrology in a Changing Environment. United Kingdom, pp. 20-32. 1998.

[47] Bultot, F., Dupriez, G.L. and Gellens, D., "Simulation of land use changes and impacts on the water balance - a case study for Belgium," Journal of Hydrology, 114, 327-348. 1990.

[48]Koehler, G. "Auswirkungen verschiedener anthropogener Veränderungen auf die Hochwasserabflüsse im Oberrhein-Gebiet, WB, 44(1), 11-15. 1992.

[49] Parkin, G., O’Donnel, G., Ewen, J., Bathurst, J. C., O'Connell, P.E. and Lavabtr, J., "Validation of catchment models for predicting land-use and climate change impacts, 2. Case study for a Mediterranean catchment," Journal of Hydrology, Vol. 175, 595-613 1996.

[50] Chang, H "Comparative Streamflow Characteristics in Urbanizing Basins in the Portland Metropolitan Area, Oregon, USA" Hydrological Processes 21, 211222. 2007.

[51] Dougherty, M., Dymond, R. L., Godrej, A. N., Grizzard, T. J., Randolp, J., and C. E. Ziper," Quantifying LonTerm Hydrologic Response in an Urbanizing Basin." Journal of Hydrologic Engineering 12, pp 33-42. 2007.

[52] Larentis, D. G., Collischonn, W., Olivena, F., Tucci, C.E.M. "GIS-based procedures for hydropower potential spotting". Energy 35, 4237-4243, 2010.

[53] Mackay DS, Robinson VB. "A multiple criteria decision support system for testing integrated environmental models." Fuzzy Set Syst ;113: 53-67. 2000 .

[54] Gassman P. W, Reyes M. R, Green C.H, Arnold J. G. "The soil and water assessment tool: historical development, applications, and future research directions." Trans ASABE;50 (4):1211-50. 2007.

[55] Ramachandra T. V, Jha R. K, Vamsee Krishna S, Shruthi B. V "Spatial decision support system for assessing micro, mini and small hydro potential." $J$ Appl Sci;4(4):, 596-604. 2004

[56] Tanabe, S. "Assessment of the Potential of Developing Mini/micro Hydropower, Master's 
Thesis, Graduate School of Environmental Science. Hokkaido University, , pp. 942015.

[57]. Fujii, M. Tanabe S,. Yamada, M and. Mishima T, Sawadate T, Ohsawa S "Assessment of the potential for developing mini / micro,"Assessment of the potential for developing mini/micro hydropower: A case study in Beppu City, Japan Masahiko Journal of Hydrology: Regional Studies http://dx.doi.org/10.1016/j.ejrh.2015.10.007

[58] Inversin, A. Micro-Hydropower SourceBook. A Practical Guide to Design and Implementation in Developing Countries.NRECA International Foundation, Washington DC, USA.1986.

[59] Otuna J. A.,.Onemano J .I; Alayande A.W “Assessment of the Hydropower Potential of Kangimi Reservoir in Kaduna State Nigeria, Nigerian Journal of TechnologyVol. 31, No. 3, pp. 300-307, 2012.

[60] United Nations Industrial Development Organization (UNIDO) .Report on Standardization of Civil Works for Small Hydro Plants. EWI Engineers \& Consultants, Zurich, Switzerland 1988.

[61] Fennessey, N and Vogel R.M. "Regional Flow Duration Curves for Ungauged Sites in
Massachusetts. J. Wat. Resource. Plan. Mang. ASCE 116 (4): pp. 530-549, 1990.

[62] Yu, P, Yang, T and Wang, Y.. "Uncertainty Analysis of Regional Flow Duration Curves." Journal of Water Resources Planning and Management128: pp 424430, 2002.

[63] Castellarin, A., Camorani, G and Brath, A. "Predicting annual and long-term flow-duration curves in ungauged basins." Advances in Water Resources30: pp937-953. 2007.

[64] Gustard, A., Bullock, A and Dixon, J. M. "Low flow estimation in the United Kingdom. Institute of Hydrology. IH report no. 108, Wallingford, UK 1992.

[65] Smakhtin, V. U. Low flow hydrology: A review. J. Hydrol 240: pp. 147-86. 2001.

[66] Karamouz, M, Szidarovszky, F and Zahraie, B. “Water resources systems analysis." New York, USA: Lewis Publishers 1991.

[67] Ramanathan K. and Abeygunawardena P. "Hydropower Development in India, A sector Assessment." Asian Development Bank (ADB) Publication Stock No. 0316072007. 